\title{
Sigara ve Periodontal Sağlık İlişkisi
}

\section{Smoking and Periodontal Health Relations}

\section{ÖZ}

Sigara, periodontal hastalık için bakteriyel plaktan sonra en güçlü modifiye edici ajan olarak tanımlanmaktadır. Sigara içen bireylerde gingivitis ve periodontitis prevalansının arttığı gözlenmektedir. Ayrıca periodontal hastalığa bağlı olarak gözlenen yıkım daha fazla görülmektedir. Sigara, içeriğindeki bazı toksik ve kanserojen maddeler ile birçok sistemik olumsuz etkiye sahip olmasının yanı sıra oral dokular üzerinde de önemli ölçüde zararlı etkilere sahiptir. Bunun yanında sigara kullanımının periodontal tedavilerin yanıtlarını da olumsuz etkilediği bilinmektedir. Sigaranın bu olumsuz etkileri hangi mekanizmalarla gerçekleştirdiği konusunda tam olarak bir fikir birliği sağlanamamıştır. Bu derlemede, sigaranın periodontal sağlık üzerine etkilerinin güncel bilgiler ışığında değerlendirilmesi amaçlanmaktadır.

Anahtar sözcükler: Sigara kullanımı, Periodontal sağlık.

\section{ABSTRACT}

Smoking was defined as the most potent modifying factor after microbial dental plaque for periodontal disease. The prevalence of gingivitis and periodontitis has increased in smokers. In addition, the destruction depending on periodontal disease has increased. Cigarette has significant systemic harmful effects with some toxic and carcinogenic substances in its contents, as well as significant harmful effects on oral tissues. Smoking also negatively affects the responses of periodontal treatments. There is not exactly a consensus on the mechanism by which the cigarettes carry out these negative effects. In this review, the effects of smoking on periodontal health was evaluated in light of current information.

Key words: Smoking, Periodontal health.

\section{GÍRIS}

Sigaranın, periodontal hastalığın insidansı ve ilerlemesinde, bakteriyel plaktan sonra en güçlü modifiye edilebilir risk faktörü olduğu bilinmektedir (1). Sigara içenlerde gingivitis ve periodontitisin daha şiddetli olduğu pek çok araştırıcı tarafından rapor edilmiştir (2-4). Sigara içenlerin ağız hijyenlerine daha az dikkat ettikleri, plak birikimlerinin daha fazla olduğu ve bu nedenden dolayı periodontal hastalığa yatkın oldukları kanısı yaygındır (5).

Sigaranın 6000'den fazla gaz veya partiküler fazda sitotoksik, mutajenik ve karsinojenik madde içerdiği bildirilmiştir. Bunlara hidrojen siyanür, azotoksitler, amonyak, katekol, formik asit gibi zehirler; arsenik, krom, nikel, benzopiren, nitrosaminaz, kadminyum, formaldehit, asetaldehit gibi kanserojen maddeler örnek gösterilebilir. Her sigara içilişinde ortalama

\section{Zeliha MUSLU \\ Hakan DEVELİOĞLU}

Cumhuriyet Üniversitesi

Diş Hekimliği Fakültesi,

Periodontoloji Anabilim Dalı, Sivas, Türkiye

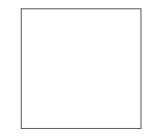

Geliş tarihi / Received: 20.12.2017

Kabul tarihi / Accepted: 17.02.2018

DOI: $\operatorname{xxxxxxxxxxx}$

İletişim Adresi/Corresponding Adress:

Zeliha MUSLU

Cumhuriyet Üniversitesi

Diş Hekimliği Fakültesi,

Periodontoloji Anabilim Dalı,

Sivas, Türkiye

Tel/Phone: 03462191010 / 2706

E-posta/e-mail: dtzelihaakkus@gmail.com 
20-30 ml karbonmonoksit ve 2-3 mg nikotinin inhale edildiği rapor edilmiştir (6).

Periodontal hastalık; enfeksiyöz ajanlar ve konak arasındaki karşılıklı kompleks ilişki sonucunda oluşur. Çevresel, kazanılmış ve genetik risk faktörleri periodontal hastalığın oluşumuna ve ilerlemesine etki eder (7). Sigara içenlerde periodontal patojen miktarı artmış olarak saptanmıştır (8).

Sigara nötrofil fonksiyonu, antikor üretimi, fibroblast aktivitesi ve enflamatuvar mediyatör üretimini içeren birçok doğal ve kazanılmış immün cevaba zarar verir. Sigara içenlerde içmeyenlere kıyasla daha derin periodontal cepler, daha fazla alveoler kemik yıkımı ve daha fazla diş kaybı olduğu bildirilmiştir $(8,9)$.

Sigara kullanım miktarı ile periodontal hastalığın görülme olasılığı ve şiddeti arasında doza bağımlı bir ilişki vardır (10). Geniş popülasyonu kapsayan bir çalışmanın sonuçlarına göre sigara kullanmayan bireylere kiyasla günde 10 sigara veya daha az sigara içenlerde periodontitis görülme olasılığ 1 2,79 iken, bu oran günde 31 veya daha fazla sigara içen bireylerde 6 katına çıkmaktadır (10). 889 kişinin katılımıyla yapılan bir diğer çalışmada ise klinik ataşman kaybı şiddetinin yıllık günde 1 sigara kullanımıyla \%0,5, 10 sigara kullanımıyla \%5 ve 20 sigara kullanımıyla \%10 oranında arttığg bildirilmiştir (11).

Kamma ve ark. yaşları 22-38 arasında değişen, sistemik açıdan sağlıklı ve agresif periodontitisli 22 bireyin subgingival floralarını, kültür alarak ve immünofluoresans ile karşılaştırmalı olarak inceledikleri çalışmalarında; klinik olarak bütün hastaların deney bölgelerinde \%98 oranında pozitif plak, \%94 oranında sondlamada kanama, \%34 oranında supurasyon tespit etmişlerdir. Mikrobiyolojik incelemelerinde bütün hastaların en az bir bölgesinde P. Intermedia, P. Gingivalis, B. Forsythus pozitif olarak bulmuşlardır. Buna karşılık hastaların \%68-95'inde C. rectus, A.a ve P. micros bulunmuştur. Sigara içenlerde A.a ve P. Micros miktarları önemli derecede fazla bulunmuştur. Bu sonuçlar, agresif periodontitisli sigara içen genç bireylerde alışılmışın dışında, B. forsythus ve P. Gingivalis prevalansının daha yüksek olduğunu göstermiştir. Buna karşılık sigara içen bireylerde A.a. ve P. micros daha düşük oranlarda görülmüştür (12).

Sigara içen bireylerin subgingival mikrofloralarını inceleyen başka çalışmalarda B. forsythus ve P. gingivalis'in baskın olduğu gösterilmiştir. Bu iki mikroorganizma sigara içenlerde mekanik tedaviyi takiben içmeyenlere nazaran daha fazla miktarda persistan kalmaktadırlar (13).

Çalışma yöntemi, çeşitli insan popülasyonları ve hastalığın şiddetinden bağımsız olarak; periodontal hastalığın sigara içenlerde içmeyenlere göre meydana gelme olasılığının daha yüksek olduğu birçok araştırmacı tarafından rapor edilmiştir $(2,3)$.

Sigara içenlerde periodontal cep derinliği, ataşman ve alveolar kemik kaybı, içmeyenlerdekinden daha fazladır. $\mathrm{Bu}$ risk sigaranın tüketim dozuna da bağlıdır. Fazla sigara tüketimi risk oranını da doğru orantılı olarak arttırmaktadır (14).

\section{Sigaranın toksik etkileri}

Sigara; karbon monoksid, oksidasyon radikalleri, nitrozamin gibi karsinojenler ve bağımlılık yaratan nikotin gibi 4000 rapor edilmiş toksik madde içermektedir(15).

Sigaranın kimyasal komponentleri hücrelerde birçok reaksiyona neden olmakta ve direkt olarak toksik hücre ölümünü başlatabilmektedir. Sigara içimi ile serumda glukoz, kortizol, serbest yağ asidi ve adrenalin düzeylerinin artarak tansiyonun, kalp hızının dolayısıyla da kalbin oksijen tüketiminin arttığı bulgulanmıştır (16).

\section{Nikotinin lokal etkileri}

Sigaranın bağımlılık yaratan komponenti olan nikotin, periodonsiyumdaki hücre gruplarına olan etkileri açısından yaygın şekilde araştırılmaktadır. Oral dokular sigara içimi esnasında yüksek dozda nikotine maruz kalır. Sigara içen bir bireyin dişeti oluğu sıvısındaki nikotin konsantrasyonu, plazma konsantrasyonundan $(20 \mathrm{ng} / \mathrm{ml})$ yaklaşık $300 \mathrm{kez}$ daha fazladır (17).

Sigaranın bırakılmasını takiben 3-5 gün içerisinde gingival kan akımı ve DOS artmaktadır. Benzer şekilde sigaranın birakılmasiyla sondlamada kanama da artmaktadır. Bu bulgular sigaranın gingival kan akımı ve vaskülariteyi baskıladığı düşüncesini desteklemektedir (18).

Nikotin sigara içenlerde kök yüzeylerine bağlanmaktadır (19). Bu şekilde gingival ve periodontal ligament fibroblastlarının tutunma ve proliferasyonlarını değiștirdiği in vitro olarak gösterilmiştir (20). Tipton ve Dabbous nikotine maruz bırakılan gingival fibroblast kültüründe kollojen üretiminin azaldığını ve kollojenaz aktivitesinin arttığını göstermişlerdir (21). Ayrıca hayvan çalışmalarında sigaranın kemik iyileşmesi üzerindeki olumsuz etkileri gözlenmiştir (22). Bu da nikotinin osteoklastik farklılaşmayı uyardığını ve anjiyogenezi etkilediğini yansıtmaktadır. Bütün bu veriler sigara içenlerde doku 
yıkımının arttığını ve iyileşmenin bozulduğunu göstermektedir.

\section{Periodontal dokular üzerine etkisi}

Sigaranın periodontal sağlık üzerindaki olumsuz etkileri tüm sistemik durumla ilişkili etkileri kadar önemlidir. Sigara yalnızca periodonsiyumdaki yıkımı artırmakla kalmaz, aynı zamanda hastalığın tanısını güçleştirir. Sigara içen bireylerde deneysel gingivitis modelinde hiperemi ve sondlamada kanama, içmeyen bireylere oranla daha az miktarda görülmüştür (23). Literatüre bakıldığında, sigaranın periodontal dokularda basit bir vazokonstrüktör etkiden ziyade vaskülarizasyon üzerinde kronik bir zarara neden olduğu kanısı karşımıza çıkmaktadır. Baskılanmış vaskülarizasyon klinikte kendini daha az gingival hiperemi ve daha az miktarda sondlamada kanama olarak göstermekte ve bu bozulmuş vaskülarizasyon iyileşmenin olumsuz etkilenmesi ile sonuçlanmaktadır (24).

Geçmiş çalışmalar sigara içenlerde daha yüksek oranda periodontitis görüldüğünü ve oral hijyenlerinin daha zayıf olduğunu, diştaşı miktarının da daha fazla olduğunu rapor etmişlerdir $(25,26)$.

Sigara içen ve içmeyen bireylerin karşılaştırıldığg çok sayıda çalışmada sigara içenlerin daha fazla kemik kaybı yaşadığ 1 ve bu bireylerde daha fazla dişeti çekilmesi gözlendiği bildirilmiştir (27). Bunun yanında, Osterberg ve Mellstrom sigara içenlerde daha fazla diş kaybı gözlendiğini rapor etmişlerdir.

Sigaranın bu etkilerini hangi mekanizma ile yaptı̆̆ kesin olarak bilinmemekle birlikte üzerinde en çok durulan teoriler sigaranın plak bakterileri, konak yanıtı ile iyileşme ve tedavi yanıtı üzerindeki etkileri yolu ile olduğu yönündedir (28).

\section{Vasküler yanıt}

Sigara gingival vaskülarizasyon üzerinde çift etkiye sahiptir. Aktif sigara içiminde intra-oral sıcaklığın artışı ile birlikte başlangıçta gingival kan akımı artar, takip eden 5 dakika içerisinde dereceli olarak azalır $(29,30)$.

Histolojik olarak sigara içen bireylerde inflame dokularda içmeyenlere kıyasla daha az sayıda kan damarları olduğu görülmüştür (31). Buna rağmen hafif ve şiddetli içicilerde sağlıklı gingivada kan akımının etkilenmediği görülmektedir. Bu da sigaranın gingival vasküler dokulardaki etkisinin inflamasyonu takiben görüldüğünü, sigaranın nedensel bir faktör olmaktan ziyade modifiye edici bir faktör olduğu konseptini desteklemektedir (32).

\section{Hücresel yanıt}

Sigaranın nötrofil fonksiyonları üzerine etkileri konusunda tartışmalı bulgular vardır. Bazı çalışmalar nötrofillerin kemotaksi ve fagositoz yeteneklerini doz bağımlı olarak baskıladığı, bazı çalışmalar ise nikotinin düşük konsantrasyonda nötrofil kemotaksisini artırdığını, yüksek konsantrasyonda ise baskıladığını bildirmektedir (32). Bu çelişkili sonuçların nötrofil yanıtını etkileyebilecek birçok kemotaktik uyaran olmasına ve nikotinin bunlardan sadece bazılarını etkileyebilmesine bağlanabileceği bildirilmiştir (33).

Sigaranın kemotaktik yanıtı üzerindeki etkileri konusunda tartışmalı sonuçlar olmasına rağmen, nötrofillerin bütün fonksiyonlarının etkilendiği ve nötrofil aktivitesinin yıkıcı yönde değiștiği konusunda fikir birliği sağlanmıştır (34). Sigaranın PMNL'den matriks metalloproteinaz üretiminin artışına sebep olduğu ve bu enzimlerin de doku yıkımında rol oynadığı bilinmektedir $(35,36)$.

\section{İmmün yanıt üzerinde etkileri}

Sigara konak yanıtını farklı yollar ile etkileyebilmekte ve böylece periodontal patojenlerin yıkıcı etkilerini artırabilmektedir. Bakteriyel plağın kompozisyonunun sigara ile değişmeyeceği ancak konak yanıtı değiştiği için verilen cevabın artabileceği yapılan çalışmalarda gösterilmiştir $(10,37)$.

Kronik periodontitis, konak yanıtı mekanizmalarından ve çevresel faktörlerden etkilenebilmektedir (38). Deneysel çalışmalar plağa bağlı gingivitis modelinde, gingival inflamasyon belirtilerinin sigara içmeyen bireylerde, içenlere nazaran baskın olduğunu göstermektedir (39). Sigaranın konak bağışıklık yanıtını etkilediğine dair yeterli kanıt mevcuttur $(1,40)$. Sigara içenlerde periodonsiyumda hemorajik yanıtın daha düşük olduğu gözlenmiştir (41). Ayrıca azalmış inflamasyon ve DOS hacmi sigaranın gingival kan akımını etkilediği görüşünü desteklemektedir. Bunun yanında sigara içenler sayıca önemli ölçüde daha fazla nötrofile sahiptir. Bu savunma hücreleri bakteriyel infeksiyonda savunmanın öncül hücreleridir, periferal dolaşımda bulunurlar. Ancak sayıca artmış olmalarına rağmen kemotaksi, fagositoz ve adherens yetenekleri azalmıştır (1). Sigara nötrofil fonksiyonunu nikotinin etkileriyle doğrudan değiştirir. Nikotin nötrofillerin degranülasyonunu artırır, ve böylece bakteri atağına karşı daha hassas bir hale getirir. Ayrıca sigara içenlerde DOS'ta TNFa' nın muhtemelen nikotine bir cevap olarak yüksek miktarda bulunduğu bildirilmiştir. TNFa ayrıca periodonsiyumda bulunan periferal nötrofillerden eksprese edilebilir ve bağ doku ve kemik yıkımında seviyeleri artmaktadır (42). 
Antikor üretimi de sigaradan etkilenen bir diğer konak yanıtı mekanizmasıdır. Sigaranın IgG serum konsantrasyonunu düşürdüğü rapor edilmiştir (43). Sigara içen bireylerde P. intermedia ve F. nukleatum gibi periodontal patojenlere karşı üretilen IgG serum titreleri ve A.a ya karşı üretilen IgG2 seviyelerinin, sigara içmeyenlere kıyasla daha düşük değerler sergiledikleri gözlenmiştir (44). Bunun yanında $\mathrm{T}$ hücre sayısının uzun süreli sigara kullanımında azaldığı da yapılan çalışmalarda bildirilmiştir $(44,45)$.

\section{Alveolar kemik kaybı}

Sigara içenlerde büyük miktarda kemik yıkımı gözlenmektedir, ayrıca yıkımın şiddeti sigara içmeyenlere kıyasla daha fazladır $(46,47)$. Bu etki doz bağımlı olarak artmakta, sigara miktarı ve kullanım süresi ile doğru orantılı bir şekilde yıkım daha fazla gözlenmektedir (48). Uzun dönem insan çalışmalarında sigara içenlerde içmeyenlere kıyasla kemikte \%10-30 daha az mineral yoğunluğu saptanmıştır. Bu durum, sigaranın kemikte D vitamini metabolizmasını veya hormonal durumu etkileyebildiğini düşündürmektedir (38). Alveolar kemik miktarı ve yoğunluğunun değerlendirildiği bir çalışmada, hastalığın bulunduğu alanlarda başlangıç ve uzun dönem karşılaştırmalı sonuçlarda sigara içmeyen ve sigarayı bırakmış kişilerde kemik kaybı miktarı stabil kalırken sigara içen bireylerde sonuçların kötüleştiği gözlenmiştir (49). Günde bir paket sigara tüketen kadın hastalar menapoza ulaştığında ortalama \%5-8 kemik yoğunluğunda kayıp yaşamaktadır. Östrojen metabolizması sigara kullanan kadınlarda değişmekte ve östrojen eksikliği IL-1,IL-6 ve TNF a ile ilişkilendirilmektedir (50).

\section{Periodontal patojenler}

Sigarada karbon monoksit gibi güçlü indirgen maddeler bulunmaktadır. Bu ajanlar direkt olarak anaeropların büyümesini artırarak yüzeysel alanlarda bile anaerop ortam oluşumuna katkıda bulunmaktadır (51). Bazı çalışmalar sigara içenlerde periodontitisle ilişkili P. gingivalis, A.a, B. forsythus, P. intermedia, Pepto micros, F. nucleatum ve C. rectus gibi bakteri türlerinin daha fazla bulunduğunu bildirmektedir $(16,45)$. Buna karşın sigara içen ve içmeyen bireylerde bulunan bakteri tiplerinin çok büyük değişkenlikler göstermediğini ancak sigaranın floranın niteliğini değiştirdiğini bildiren çalışmalar da bulunmaktadır. Sigara kullanan bireylerde periodontal ceplerde azalmış oksijen yoğunluğu anaerobik bakterilerin üremesinde etkili olabilmektedir (50).
Ayrıca, dental plaktaki oksidasyon redüksiyon potansiyelleri sigarayla birlikte azalmakta ve anaerop bakterilerin üremesi için uygun ortam oluşturmaktadır (43). Deneysel çalışmalar sigara ile plak formasyonu arasında güçlü bir ilişki kuramazken sigara içen bireylerde supragingival plağa verilen konak yanıtının değiştiği gözlenmiştir. Ayrıca bazı kesitsel çalışmalarda sigara içen bireylerde içmeyenlere oranla daha fazla plak ve diştaşı oluşumu gözlendiği rapor edilmiştir (52).

\section{Yara iyileșmesi üzerine etkileri ve periodontal tedaviye yanit}

Sigara içenlerde periodontal hastalığın yüksek oranda görülmesi ve bozulmuş yara iyileşmesini açıklamaya çalışan birkaç olası mekanizma bulunmasına rağmen kanıtlanmış kesin bir mekanizma bulunmamaktadır. Sigaraya verilen farklı yanitlar (subgingival floranın daha patojenik hale gelmesi, azalmış mikrosirkülasyon, nötrofil disfonksiyonları, proinflamatuar sitokinlerin artması ve patojenik T hücre seviyelerinin artması gibi) rol oynuyor olabilirler (14).

Sigara içen bireyler periodontal tedaviye içmeyenlere göre daha kötü yanıt vermektedir $(53,54)$. Çalışmalar göstermektedir ki, periodontal tedavinin farkl formlarında sigara iyileşmeyi olumsuz etkilemektedir (50). Sigarayı bırakmış bireylerin sigara içmeyenlerle benzer tedavi yanıtı gösterdiği gözlenmiştir ve bu yüzden sigarayı bırakmanın iyileşmeye olumlu etkileri olacağ 1 düşünülmektedir (55). Eski içici veya sigara içmeyen bireylerle kıyaslandığında, sigara içenlerin periodontal tedavi sonrasi cep derinliklerinde daha az azalma, daha az klinik ataşman kazancı gözlenmiştir (6). 6 yıllık takip sonuçlarının bulunduğu bir çalışmada periodontal tedavi sonrası sigara içmeyenlerde içenlere göre cep derinliğinde \%50 daha fazla azalma ve klinik ataşman kazancı elde edilmiștir (56).

Cerrahi olmayan periodontal tedaviye yanıt, sigara içenlerde içmeyenlere oranla klinik parametrelerinde daha az kazanç gözlenir ve bu fark özellikle de ataşman kaybının $5 \mathrm{~mm}$ veya üzerinde olduğu bölgelerde daha belirgindir $(7,57)$. Sigara içenlerde cerrahi olmayan tedavi ile subgingival patojenleri elimine etmek daha zor olacağ 1 için bazı klinisyenler yardımcı antimikrobiyallerin kullanımını önermektedirler. Fakat sistemik antibiyotiklerin sigara içen bireylerde tedaviye katkıları konusunda tartışmalı sonuçlar bulunmaktadır $(8,45)$. Lokal uygulanan ajanlarda, SRP ye ek olarak doksisiklin ve minosiklin ile elde edilen sonuçlar, sigara içmeyen bireylerin tedaviye verdiği cevap ile eşdeğer bulunmuştur $(58,59)$. 
Dahası yakın zamanda yapılmış bir sistematik derlemede yönlendirilmiş kemik rejenerasyonu ile tedavi edilen kemik içi defektlerde sigaranın kemik rejenerasyonunu önemli ölçüde olumsuz etkilediği belirtilmiştir (60). Kök yüzeyi kapatma işlemleri de benzer şekilde sigara içen bireylerde daha başarısız bulunmuştur (61-63).

Sigarada bulunan kimyasal ürünler ve toksinler hücresel fonksiyonları baskılayarak yara iyileşmesini geciktirebilmektedir. Sigara, rejeneratif tedavide güçlü bir negatif etkiye neden olmaktadır. Sigaranın sebep olduğu vaskülarizasyondaki değişimler sert ve yumuşak dokuları etkileyerek yara iyileşmesinde (özellikle rejeneratif, periodontal ve implant tedavilerinde) önemli bir negatif etki yaratabilmektedir. Sigaranın volatil komponentleri olan akrolein ve asetaldehit, gingival fibroblastları inhibe ederek bağlanma ve çoğalmalarını engelleyebilir. Ayrıca nikotine maruz kalan fibroblastlar daha az fibronektin ve kollojen üretirken daha fazla kollojenaz üretir. Periodonsiyumdaki fibroblastların proliferasyon, kemotaksi ve bağlanma yetenekleri nikotin tarafından inhibe edilir $(53,64)$. Bu etkiler nikotinin kök yüzeyine tutunması ile artabilmekte ve periodontal rejenerasyonu baskılayabilmektedir. Fibroblast üzerindeki bu olumsuz etkiler, yara iyileşmesini olumsuz etkilemekte ve periodontitisin ilerlemesinde önemli bir rol oynamaktadır (56). Ayrıca sigara CD3, CD4 ve CD8 T hücre alt gruplarının artmasina sebep olabilmekte ve böylece periodontal yıkımın şiddetlendirmektedir (65).

\section{İmplant başarısı}

Sigara kullanımının implant uygulamaları üzerine olan etkisini ilk olarak Bain ve Moy 1993 yılında araştırmıştır ve sigara kullanımının implant uygulamalarında karşılaşılan başarısızlıkların en önemli nedenlerinden biri olduğunu bildirmişlerdir (66).

Sigara kullanımın implant başarısına etkisini değerlendiren en geniş veriye sahip çalışma; Lambert ve arkadaşlarının yaptığı, \% 62 sini hidroksiapatit kaplı implantların oluşturduğu, 800 hastada toplam 2887 implantın dahil edildiği, 2000 yılında yayınlanmış olan 8 yıllık prospektif bir çalışmadır. Bu çalışmanın sonuçlarına göre implant başarısızlık oranları sigara içenlerde sigara içmeyenlere kıyasla daha fazla bulunmuştur ve bu başarısızlık oranını azaltmak için operasyon öncesi antibiyotik kullanımı önerilmiştir (67).

Sigara implant faili için bir risk faktörü olarak tanımlanmıştır. Maksiller implant failleri sigara içenlerde (\%10.9) içmeyen veya sigarayı bırakmış bireylere(\%6.4) göre daha fazla görülmektedir (67). Güncel bir sistematik derlemede implant sağkalım oranları sigara içen bireylerde \%86 iken içmeyenlerde \%92 olarak bildirilmiştir (68). Diğer yandan bazı çalışmalar anterior mandibula ve mandibular molar sahalarda implant sağkalımının sigaradan etkilenmediği ve hafif sigara içiminde (günde 12 adetten az) sağkalımın implant yüzey özelliklerinden etkilenmediği bildirilmiştir $(69,70)$. Ancak 19 ve 29 çalışmayı kapsayan iki meta analiz çalışmasında sigara içiminin implant faili için yüksek oranda ilişkili olduğu, özellikle de maksillada ogmentasyon prosedürleri ile birlikte uygulamada fail riskinin arttığı bildirilmiştir $(71,72)$.

Peri-implant kemik kaybının değerlendirildiği araştırmalarda sigara içenlerde içmeyenlere kıyasla periimplant hastalık olasılığı daha yüksek bulunmuştur. Ayrıca 2010 yılındaki bir çalışmaya göre nikotin ortodontik mini vidaların başarısını da negatif yönde etkilemektedir (73).

\section{Oral kanserler}

Sigara ile ilişkilendirilen kanserler arasında en sik görülen akciğer kanseridir ve onu sirasiyla larinks kanseri ve oral kanserler takip eder. Son on yllda birçok ülkede oral kanser riski artmıştır. Bu ülkelerde yapılan epidemiyolojik çalışmalara göre bu risk sigara içen bireylerde içmeyenlere göre 3 kat daha yüksektir (74). İtalya'da yapılan bir çalışmanın sonuçlarına göre oral kanserlerle ilişkilendirilebilen izole en büyük risk kaynağ 1 sigara olarak bulunmuş. Ayrıca içilen sigara miktarı ile orantılı olarak riskin arttığı gözlenmiştir (75).

\section{Sigaranın bırakılması}

Sigaranın bırakılmasından sonra etkileri hemen kaybolmamaktadır (76). Sigara içenlerde iyileşme olumsuz etkilenirken sigaranın birakılmasının cerrahi veya cerrahi olmayan tedavi esnasinda bile tedavinin sonuçlarını iyileştirdiği ve komplikasyonların daha az görüldügü gözlenmiştir $(77,78)$. Sigara bıraktırma programlarının rutin bir şekilde tedavi planlarına dahil edilmesi gerektiği ve sigara içiminin periodontal tedavi için bir kontrendikasyon olmaması gerektiği bildirilmiştir (32).

Yapılan çalışmalarda, sigarayı bırakmış bireylerin cerrahi olmayan ve cerrahi periodontal tedaviye cevapları ve implant başarı oranları hiç sigara içmeyenler ile benzer bulunmuştur (6). Barrera ve ark. sigaranın cerrahi operasyonlardan 6-8 hafta önce birakılması durumunda operasyon sonrası komplikasyonlarda önemli ölçüde azalma gözlendiğini rapor etmişlerdir (79). 


\section{TARTIŞMA}

Sigara içimi periodontal hastalığın görülme olasıllı̆ı ve hastalığın şiddeti için majör bir risk faktörüdür (80). Kesitsel çalışmalar sigara içenlerin periodontitise yatkınlığının, sigara içmeyen bireylere göre 2-7 kat arttığını göstermektedir (81). Ayrıca idame tedavisinde diş kaybı da sigara içenlerde daha fazla görülmektedir.

Sigara içen bireyler içmeyenlere göre cerrahi ve cerrahi olmayan periodontal tedaviye daha kötü yanıt göstermektedirler $(81,82)$.

Sigara ile ilgili yapılan çalışmalarda sigara içenlerde içmeyenlere kıyasla daha derin periodontal cepler, artmış ataşman kaybı ve artmış diş kaybı gözlendiği bildirilmiştir (27, 39, 83). Mahuca ve ark. sigaranın periodontal hastalık üzerindeki etkilerini araştırdıkları çalışmalarında sigara içmeyenlerde daha yüksek plak ve kanama indeks skorları elde ederken, sigara içenlerde ise daha yüksek cep derinliği ve ataşman kaybı gözlemişlerdir (54). Bergstrom ve ark. da benzer şekilde sigara içen bireylerde daha derin sondlama değerleri ve daha fazla alveolar kemik kaybı gözlemişlerdir (84). Ayrıca sigara kullanımı ile periodontal ataşman kaybı arasındaki ilişkinin doza bağımlı bir şekilde geliştiğini bildiren çalışmalar da bulunmaktadır $(27,85)$.

Sigaranın etkileri kümülatifdir. Sigara kullanım süresi arttıkça görülen periodontal yıkım da artmaktadır (86). Sigaranın birakılması ile hastanın periodontal durumu iyileşebilmektedir. Sigarayı bırakmış bireyler sigara içenlerle kıyaslandığında periodontitisten daha az etkilenmiş alan veya daha düşük şiddette hastalık sergilemektedirler $(10,46)$. Fakat hiç sigara içmeyenlerin risk seviyesine ulaşmaları için uzun yıllar gerekebilmektedir (10).

\section{KAYNAKLAR}

1. Johnson GK, Guthmiller JM. The impact of cigarette smoking on periodontal disease and treatment. Periodontol. 2000 2007;44(1):178-194.

2. Eke PI, Wei L, Borgnakke WS, Thornton-Evans G, Zhang $\mathrm{X}, \mathrm{Lu} \mathrm{H}$, McGuire LC, Genco RJ. Periodontitis prevalence in adults $\geq 65$ years of age, in the USA. Periodontol. 2000 2016;72(1):76-95.

3. Ziukaite L, Slot D, Loos B, Coucke W, Van der Weijden G. Family history of periodontal disease and prevalence of smoking status among adult periodontitis patients: a crosssectional study. Int. J. Dent. Hyg. 2016;1-7.
4. Akinkugbe AA, Sanders AE, Preisser JS, Cai J, Salazar CR, Beck JD. Environmental tobacco smoke exposure and periodontitis prevalence among nonsmokers in the hispanic community Health Study/Study of Latinos. Community Dent. Oral Epidemiol. 2017;45(2):168-177.

5. Chaffee BW, Couch ET, Ryder MI. The tobacco-using periodontal patient: Role of the dental practitioner in tobacco cessation and periodontal disease management. Periodontol. 2000 2016;71(1):52-64.

6. Alkan EA, Dikilitaş A, Alkan Ö, Parlar A. Sigara ve periodontal hastalık ilişkisi. Acta Odontol. Turc. 2013;30(1):49-53.

7. Labriola A, Needleman I, Moles D. Systematic review of the effect of smoking on nonsurgical periodontal therapy. Periodontol. 2000 2005;37:124-37.

8. Velden U Van der, Varoufaki A. Effect of smoking and periodontal treatment on the subgingival microflora. $J$. Clin.Periodontol 2003;30(7):603-610.

9. Axelsson P, Paulartder J. Relationship between smoking and dental status in 35-, 50-, 65-, and 75-year-old individuals. J. Clin.Periodontol 1998;25(4):297-305.

10. Tomar S, Asma S. Smoking-attributable periodontitis in the United States: findings from NHANES III. J. Periodontol. 2000;71(5):743-751.

11. Martinez-Canut P, Lorca A. Smoking and periodontal disease severity. J. Clin. Periodontol. 1995;22(10):743-749.

12. Kamma JJ, Nakou M, Subgingival microflora associated with early onset periodontitis patients. Europerio 2, Abstract of Clinical, Research and Poster Presentations selected for publication. J Clin. Periodontol 1997;24:845872.

13. Bergström J. Tobacco smoking and chronic destructive periodontal disease. Odontology 2004;92(1):1-8.

14. Genco RJ, Borgnakke WS. Risk factors for periodontal disease. Periodontol. 2000 2013;62:59-94.

15. Heasman L, Stacey F, Preshaw P. The effect of smoking on periodontal treatment response: a review of clinical evidence. J. Clin.Periodontol 2006;33(4):241-253.

16. Zambon J, Grossi S, Machtei E. Cigarette Smoking Increases the Risk for Subgingival Infection With Periodontal Pathogens. J.Periodontol 1996;67(10):1050-1054.

17. Ryder MI, Fujitaki R, Lebus S, Mahboub M, Faia B, Muhaimin D, Hamada M, Hyun W. Alterations of neutrophil L-selectin and CD18 expression by tobacco smoke: implications for periodontal diseases. J. Periodontal Res. 1998;33(6):359-68.

18. Morozumi T, Kubota T, Sato T, Okuda K, Yoshie H. Smoking cessation increases gingival blood flow and gingival crevicular fluid. J. Clin. Periodontol. 2004;31(4):267-72.

19. Chang Y, Huang F, Tai K. Mechanisms of cytotoxicity of nicotine in human periodontal ligament fibroblast cultures in vitro. J. Periodontal Res. 2002;37(4):279-285. 
20. Gamal A, Bayomy M. Effect of cigarette smoking on human PDL fibroblasts attachment to periodontally involved root surfaces in vitro J. Clin. Periodontol. 2002;29(8):763-770.

21. Tipton D, Dabbous M. Effects of nicotine on proliferation and extracellular matrix production of human gingival fibroblasts in vitro. J. Periodontol. 1995;66(12):1056-1064.

22. Carvalho M, Benatti B. Effect of cigarette smoke inhalation and estrogen deficiency on bone healing around titanium implants: a histometric study in rats. J. Periodontol. 2006;77(4):599-605.

23. Bergström J, Preber H. The influence of cigarette smoking on the development of experimental gingivitis. $J$. Periodontal Res. 1986;21(6):668-676.

24. Palmer R, Wilson R, Hasan AS, Scott DA. Mechanisms of action of environmental factors-tobacco smoking. J. Clin. Periodontol. 2005;32(6): 180-95.

25. Alexander A. The relationship between tobacco smoking calculus and plaque accumulation and gingivitis. Dent. Health 1969;9(1):6-9.

26. Brandtzaeg P, Jamison $\mathrm{H}$. A study of periodontal health and oral hygiene in Norwegian army recruits. J. Periodontol. 1964;35(4):302-307.

27. Haffajee A, Socransky S. Relationship of cigarette smoking to attachment level profiles. J. Clin. Periodontol. 2001;28(4):283-295.

28. Khan S. Effect of smoking on periodontal health. Dis. Mon. 2011;57(4):214-7.

29. Mavropoulos A, Aars H, Brodin P. Hyperaemic response to cigarette smoking in healthy gingiva. J. Clin. Periodontol. 2003;30(3):214-221.

30. Meekin T, Wilson R, Scott D, Ide M. Laser Doppler flowmeter measurement of relative gingival and forehead skin blood flow in light and heavy smokers during and after smoking. J. Clin. Periodontol. 2000;27(4):236-242.

31. Rezavandi K, Palmer R, Odell E. Expression of ICAM-1 and E-selectin in gingival tissues of smokers and non-smokers with periodontitis. J. Oral Pathol. Med. 2002;31(1):59-64.

32. Knight, Ellie. T. Jenny Liu, Gregory J. Seymour CMFJ \&Mary PC. Risk factors that may modify the innate and adaptive immune responses in periodontal diseases. Periodontol. 2000 2016;71(1):22-51.

33. Palmer R, Wilson R, Hasan A. Mechanisms of action of environmental factors-tobacco smoking. J. Clin. Periodontol. 2005;32(6):180-195.

34. Van Eeden SF, Hogg JC. The response of human bone marrow to chronic cigarette smoking. Eur. Respir. J. 2000;15(5):915-921.

35. Persson L, Bergström J, Ito H. Tobacco smoking and neutrophil activity in patients with periodontal disease. $J$. Periodontol. 2001;72(1):90-95.

36. Söder B, Jin L, Wickholm S. Granulocyte elastase, matrix metalloproteinase-8 and prostaglandin E2 in gingival crevicular fluid in matched clinical sites in smokers and non-smokers with. J. Clin. Periodontol. 2002;29(5):384391.
37. Darby I, Hodge P, Riggio M. Clinical and microbiological effect of scaling and root planing in smoker and nonsmoker chronic and aggressive periodontitis patients. J. Clin. Periodontol. 2005;32(2):200-206.

38. Gelskey S. Cigarette smoking and periodontitis: methodology to assess the strength of evidence in support of a causal association. Community Dent. Oral Epidemiol. 1999;27(1):16-24.

39. Van der Weijden GA, De Slegte C, Timmerman MF, Van der Velden U. Periodontitis in smokers and non-smokers: intra-oral distribution of pockets. J. Clin. Periodontol. 2001;28(10):955-960.

40. Kinane D, Chestnutt I. Smoking and periodontal disease. Crit. Rev. Oral Biol. Med. 2000;11(3):356-365.

41. Bergström J, Boström L. Tobacco smoking and periodontal hemorrhagic responsiveness. J. Clin. Periodontol. 2001;28(7):680-685.

42. Söder B, Nedlich U, Jin L. Longitudinal effect of nonsurgical treatment and systemic metronidazole for 1 week in smokers and non-smokers with refractory periodontitis: a 5-year study. J. Periodontol. 1999;70(7):761-771.

43. Haffajee A, Socransky S. Relationship of cigarette smoking to the subgingival microbiota. J. Clin. Periodontol. 2001;28(5):377-388.

44. Mooney J, Hodge P, Kinane D. Humoral immune response in early-onset periodontitis: influence of smoking. J. Periodontal Res. 2001;36(4):227-232.

45. Winkelhoff A, Bosch-Tijhof C. Smoking affects the subgingival microflora in periodontitis. J. Periodontol. 2001;72(5):666-671.

46. Bergström J, Eliasson S, Dock J. A 10-year prospective study of tobacco smoking and periodontal health. J. Periodontol. 2000;71(8):1338-1347.

47. Kerdvongbundit V, Wikesjö UM. Effect of smoking on periodontal health in molar teeth. J. Periodontol. 2000;71(3):433-437.

48. Ashril N, Al-Sulamani A. The effect of different types of smoking habits on periodontal attachment. J. Int. Acad. Periodontol. 2003;5(2):41-46.

49. Torrungruang K, Nisapakultorn K, Sutdhibhisal S. The effect of cigarette smoking on the severity of periodontal disease among older Thai adults. J. Periodontol. 2005;76(4):566-572.

50. Johnson G, Slach N. Impact of tobacco use on periodontal status. J. Dent. Educ. 2001;65(4):313-321.

51. Eggert F, McLeod M, Flowerdew G. Effects of smoking and treatment status on periodontal bacteria: evidence that smoking influences control of periodontal bacteria at the mucosal surface of the gingival. J. Periodontol. 2001;72(9):1210-1220.

52. Müller H, Stadermann S, Heinecke A. Bleeding on probing in smokers and non-smokers in a steady state plaque environment. Clin. Oral Investig. 2001;5(3):177-184. 
53. James J, Sayers N, Drucker D. Effects of tobacco products on the attachment and growth of periodontal ligament fibroblasts. J. Periodontal Res. 1999;70(5):518-525.

54. Machuca G, Rosales I, Lacalle J. Effect of cigarette smoking on periodontal status of healthy young adults. $J$. Periodontol. 2000;71(1):73-78.

55. Winn D. Tobacco use and oral disease. J. Dent. Educ. 2001;65(4):306-312.

56. Johnson G, Hill M. Cigarette smoking and the periodontal patient. J. Periodontol. 2004;75(2):196-209.

57. Preshaw, P. M., Lauffart, B., Zak, E., Jeffcoat, M. K., Barton I. Progression and treatment of chronic adult periodontitis. J. Periodontol. 1999;70(10):1209-1220.

58. Williams R, Paquette D, Offenbacher S. Treatment of periodontitis by local administration of minocycline microspheres: a controlled trial. J. Periodontol. 2001;72(11):1535-1544.

59. Tomasi C, Wennström J. Locally delivered doxycycline improves the healing following non-surgical periodontal therapy in smokers. J. Clin. Periodontol. 2004;31(8):589595.

60. Patel R, Wilson R, Palmer RM. The effect of smoking on periodontal bone regeneration: a systematic review and meta-analysis. J. Periodontol. 2012;83(2):143-155.

61. Silva C, Sallum A, Lima A de. Coronally positioned flap for root coverage: poorer outcomes in smokers. J. Periodontol. 2006;77(1):81-87.

62. Martins A, Andia D, Sallum A. Smoking may affect root coverage outcome: A prospective clinical study in humans. J. Periodontol. 2004;75(4):586-591.

63. Erley K, Swiec G, Herold R. Gingival recession treatment with connective tissue grafts in smokers and non-smokers. J. Periodontol. 2006;77(7):1148-1155.

64. Cuff M, McQuade M, Scheidt M. The presence of nicotine on root surfaces of periodontally diseased teeth in smokers. J. Periodontol. 1989;60(10):564-569.

65. Loos B, Roos M, Schellekens P. Lymphocyte numbers and function in relation to periodontitis and smoking. $J$. Periodontol. 2004;75(4):557-564.

66. Bain C, Moy P. The association between the failure of dental implants and cigarette smoking.. J. Oral Maxillofac. Implant. 1993;8(6):191.

67. Lambert P, Morris H, Ochi S. The influence of smoking on 3-year clinical success of osseointegrated dental implants. Ann. Periodontol. 2000;5(1):79-89.

68. Klokkevold P, Han T. How do smoking, diabetes, and periodontitis affect outcomes of implant treatment?. Int. J. Oral Maxillofac. Implants 2007;22(7):173-202.

69. Wallace R. The relationship between cigarette smoking and dental implant failure. Eur. J. Prosthodont. Restor. Dent. 2000;8(3):103-106.
70. Levin L, Sadet P, Grossmann Y. A retrospective evaluation of 1,387 single-tooth implants: a 6-year follow-up. J. Periodontol. 2006;77(12):2080-2083.

71. Hinode D, Tanabe S, Yokoyama M. Influence of smoking on osseointegrated implant failure: a meta-analysis. Clin. Oral Implants Res. 2006;17(4):473-478.

72. Strietzel F, Reichart P, Kale A. Smoking interferes with the prognosis of dental implant treatment: a systematic review and meta-analysis. J. Clin. Periodontol. 2007;34(6):523544.

73. Bayat E, Bauss O. Effect of smoking on the failure rates of orthodontic miniscrews. J. Orofac. Orthop. 2010;71(2):117124.

74. Warnakulasuriya S. Global epidemiology of oral and oropharyngeal cancer. Oral Oncol. 2009;45(4):309-316.

75. Negri E, Vecchia C La, Franceschi S, Tavani A. Attributable risk for oral cancer in northern Italy.. Cancer Epidemiol. Prev. Biomarkers 1993;2(3):189-193.

76. Jansson L, Lavstedt S. Influence of smoking on marginal bone loss and tooth loss-a prospective study over 20 years. J. Clin. Periodontol. 2002;29(8):750-756.

77. Peleg M, Garg A, Mazor Z. Healing in smokers versus nonsmokers: survival rates for sinus floor augmentation with simultaneous implant placement. Int. J. Oral Maxillofac. Implant. 2006;21(4):551.

78. Preshaw P, Heasman L, Stacey F. The effect of quitting smoking on chronic periodontitis. J. Clin. Periodontol. 2005;32(8):869-879.

79. Barrera R, Shi W, Amar D, Thaler H. Smoking and timing of cessation: impact on pulmonary complications after thoracotomy. Chest J. 2005;127(6):1977-1983.

80. Luzzi L, Greghi S, Passanezi E. Evaluation of clinical periodontal conditions in smokers and non-smokers. J. Appl. Oral Sci. 2007;15(6):512-517.

81. Chambrone L, Chambrone D, Lima L. Predictors of tooth loss during long-term periodontal maintenance: a systematic review of observational studies. J. Clin. Periodontol. 2010;37(7):675-684.

82. Wan C, Leung W, Wong M, Wong R. Effects of smoking on healing response to non-surgical periodontal therapy: a multilevel modelling analysis. J. Clin. Periodontol. 2009;36(3):229-239.

83. Maatouk F, Maatouk W, Ghedira H, Mimoun S Ben. Effect of 5 years of dental studies on the oral health of Tunisian dental students. East. Mediterr. Heal. J. 2006;12(5):625.

84. Bergström J, Eliasson S, Preber H. Cigarette smoking and periodontal bone loss. J. Periodontol. 1991;62(4):242-246.

85. Obradovic R, Kesic L, Mihailovic D, Ignjatovic N. Comparative efficacy analysis of biomaterials and soft lasers in repair of bone defects. J Oral Laser Appl 2007;7:161-166.

86. Bergström J, Eliasson S, Dock J. Exposure to tobacco smoking and periodontal health.J. Clin. Periodontol. 2000;27(1):61-68. 